CrimRxiv •

\title{
Health Implications of
} Incarceration and Reentry on Returning Citizens: A Qualitative Examination of Black Men's Experiences in a Northeastern City Jason M. Williams, Sean K. Wilson, Carrie Bergeson

Published on: Aug 04, 2020

License: Creative Commons Attribution 4.0 International License (CC-BY 4.0). 
